\title{
Dampak Deraan Kekeringan pada Fase Inisiasi Bunga, Fase Berbunga dan Fase Pembentukan Polong terhadap Pembentukan Bunga dan Buah pada Empat Varietas Vigna radiata
}

\author{
Effect of Drought on the Stage of Flower Initiation, Flowering and Fruiting to \\ Development of Flower and Pod in four varieties of Vigna radiata
}

\author{
Mangadas Lumban Gaol ${ }^{*}$, Maria Longa Ruma ${ }^{1}$, Hery Leo Sianturi \\ ${ }^{1}$ Jurusan Biologi Fakultas Sains dan Teknik, Universitas Nusa Cendana, Jl. Adisucipto Kupang NTT 85001 \\ E-mail: lumbanbio@yahoo.co.id *Penulis untuk korespondensi \\ ${ }^{2}$ Jurusan Fisika Fakultas Sains dan Teknik, Universitas Nusa Cendana, Jl. Adisucipto Kupang NTT 85001
}

\begin{abstract}
One of the greatest affected factors toward the growth of $V$. radiata is considered as the availability of water. Obviously, less production of $V$. radiata is due to short water supply. This research shows that flower initiation, flowering and fruiting to reproduction of four $V$. radiata varieties (Belu, Kenari, Perkutut and Murai), affected by drought are taken under this investigation. Based on numbers of initiated pod flowers and pods being produced, the most sensitive reproduction stages to drought in Belu variety were flower initiation and flowering, Kenari variety were flowering, Murai variety were flowering and fruiting, and Perkutut variety in all reproduction stages posses relatively similar level of sensitivity to drought. Generally, number of flowers initiated pods and the number of pods produced were higher in Kenari and Murai varieties compared to those on Perkutut and Belu. Based on numbers of flowers initiated pods and numbers of pods production, drought at flower initiation and flowering stage were more highly affected on Belu and Perkutut varieties compared to that of Kenari and Murai. Droughts on fruiting stage are highly affected on Perkutut varieties as well compared to other varieties. Therefore, based on plants production and their tolerance to drought, the best plants to be cultivated are Kenari and Murai.
\end{abstract}

Key words: $V$. radiata, drought, flower, pods and variety

Diterima: 11 September 2008, disetujui: 12 Januari 2009

\section{Pendahuluan}

Kacang hijau (Vigna radiata L.) di Indonesia mempunyai peranan penting dalam mendukung keanekaragaman pangan, merupakan sumber gizi terutama protein nabati dan juga sebagai bahan baku industri dan pupuk. Di Indonesia, provinsi NTT (Nusa Tenggara Timur) merupakan salah satu sentra produksi kacang hijau dan pada Tahun 2002, Kabupaten Belu telah ditetapkan sebagai salah satu kawasan agrobisnis kacang hijau.

Di NTT, kacang hijau umumnya ditanam di lahan tadah hujan dan lahan kering. Salah satu faktor yang sangat mempengaruhi suksesnya budidaya kacang hijau di NTT adalah ketersediaan air. Sesuai dengan kondisi iklim NTT, yaitu curah hujan yang rendah, kekurangan air hampir terjadi setiap tahun dan kekurangan air ini sering bertepatan dengan fase reproduksi tanaman annual yang dibudidayakan. Pertumbuhan dan produksi kacang hijau sering menurun akibat kekurangan air.

Pada daerah beriklim kering, seperti NTT varietas tanaman yang tahan terhadap deraan kekeringan, efisien menggunakan air, 
laju pertumbuhan cepat dan banyak mengalokasikan hasil assimilasinya ke organ reproduksi cocok dibudidayakan. Beberapa penelitian menunjukkan bahwa toleransi kacang hijau terhadap deraan kekeringan berbeda antar varietas (Moenandir et al., 1990; Sumarno et al., 1993; Sathyamoorthi et al., 2008). Oleh sebab itu, untuk mengoptimalkan produksi perlu menanam varietas yang lebih tahan terhadap deraan kekeringan.

Kepekaan tumbuhan terhadap deraan kekeringan air berkaitan dengan fase fenologi pertumbuhan dan perkembangan tumbuhan. Pada Vicia faba misalnya, deraan kekeringan pada periode perkembangan polong sampai pembentukan polong yang sempurna mengurangi hasil biji sampai $45 \%$ sedang jika deraan kekeringan terjadi sesudah berbunga akan mengurangi jumlah polong dan biji per tanaman sampai 38\% (Xia, 1997). Hasil penelitian tersebut menunjukkan bahwa deraan kekeringan selama fase pengisian polong mengurangi berat biji. Menurut Mwanamwenge et al., (1999), pada V. faba tahap awal pembentukan polong merupakan fase yang paling sensitif terhadap deraan kekeringan. Menurut Xia (1994), jika selama fase reproduksi terjadi deraan kekeringan pembentukan polong akan berkurang akibat terjadinya aborsi bunga dan polong berukuran kecil.

Respon empat varietas kacang hijau (satu varietas lokal Belu dan tiga varietas unggul nasional: Kenari, Perkutut dan Murai) terhadap deraan kekeringan diteliti. Keempat varietas diduga potensial dikembangkan di NTT karena produksinya relatif tinggi (Hakim, 2008), namun demikian adaptasinya terhadap kondisi lingkungan, khususnya terhadap deraan kekeringan belum banyak diketahui. Permasalahan yang ingin dikaji adalah bagaimanakah dampak dari deraan kekeringan pada fase inisiasi bunga, fase berbunga dan fase pembentukan polong terhadap reproduksi varietas-varietas kacang hijau tersebut.

\section{Metode Penelitian}

Penelitian dilakukan pada Bulan MaretJuni 2008 di Rumah Kaca dan Laboratorium Jurusan Biologi Fakultas Sains dan Teknik
(FST) Universitas Nusa Cendana. Biji varietas lokal Belu diperoleh dari Balai Penelitian Tanaman Pangan dan Holtikultur Pertanian Naibonat Kupang NTT sedangkan biji varietas Kenari, Perkutut dan Murai diperoleh dari Balai Penelitian Tanaman Kacang-kacangan dan Umbi-umbian Unit Produksi Benih Sumber Kendalpayak Malang.

Media tanam terdiri dari campuran pasir sungai dengan tanah humus dengan perbandingan 1:2. Untuk meningkatkan kesuburan tanah, media tanam diberi pupuk NPK sebanyak 5 g per pot. Tiga biji dari setiap varietas ditanam dalam pot berukuran delapan liter. Anakan yang tumbuh pada tiap pot kemudian dikurangi menjadi satu tanaman per pot setelah benih mencapai ketinggian sekitar 5 $\mathrm{cm}$ dari permukaan tanah. Pengendalian hama dan penyakit tanaman dilakukan dengan menggunakan pestisida.

\section{Desain eksperimen dan pengukuran parameter}

Penelitian terdiri dari 4 perlakuan varietas, 4 perlakuan deraan kekeringan pada fase fenologi reproduksi tanaman yang berbeda dan 5 ulangan. Perlakuan deraan kekeringan adalah: tidak ada perlakuan deraan kekeringan sebagai kontrol (S0), deraan kekeringan pada fase inisiasi bunga (S1), deraan kekeringan pada fase berbunga (S2, 50\% tumbuhan mempunyai satu bunga terbuka) dan deraan kekeringan pada fase pembentukan polong (S3, 50\% tumbuhan mempunyai satu polong panjang sekitar $5 \mathrm{~cm}$ ). Perlakuan deraan kekeringan dilakukan dengan cara menghentikan suplai air pada setiap fase fenologi perkembangan tanaman sampai pada level 40\% kapasitas lapang tanah. Stres air yang diterapkan levelnya sama pada setiap varietas dan setiap fase fenologi perkembangan tanaman sesuai perlakuan. Parameter yang diukur adalah jumlah bunga membentuk polong dan jumlah polong yang dihasilkan oleh setiap tanaman.

\section{Analisis Data}

Untuk mengetahui pengaruh perlakuan terhadap parameter-parameter penelitian yang diukur, data dianalisis dengan analisis varians. Jika perlakuan mempunyai pengaruh yang 
nyata, analisis data dilanjutkan dengan uji beda nyata terkecil. Analisis data dilakukan dengan menggunakan program Minitab.

\section{Hasil dan Pembahasan}

\section{Varietas Belu}

Pada varietas Belu, deraan kekeringan pada fase inisiasi bunga dan berbunga menyebabkan jumlah bunga membentuk polong rendah (Gambar 1a). Pada tanaman kontrol (tidak ada perlakuan deraan kekeringan), rata-rata jumlah bunga membentuk polong per tanaman adalah 5.00 (1.21), kekeringan pada fase inisiasi bunga $1.60(0.84)$, kekeringan pada fase berbunga $0.80(0.30)$ dan kekeringan pada fase pembentukan polong 4.75 (1.05). Deraan kekeringan juga mempengaruhi hasil polong $(\mathrm{P}<0.001)$. Pada tanaman kontrol (Gambar 1b), rata-rata jumlah polong per tanaman adalah 16.20 (2.86), kekeringan pada fase inisiasi bunga 2.60 (0.94), kekeringan pada fase berbunga 2.40 (0.82) dan kekeringan pada fase pembentukan polong adalah 11.25 (2.18).

Umumnya, deraan kekeringan pada fase reproduksi menyebabkan produksi polong menurun. Deraan kekeringan pada fase inisiasi bunga dan berbunga dampaknya lebih besar dibanding dengan deraan kekeringan pada fase pembentukan polong. Jadi, pada varietas Belu fase reproduksi yang paling rentan terhadap deraan kekeringan adalah fase inisiasi bunga dan berbunga.

\section{Varietas Perkutut}

Pada varietas Perkutut, deraan kekeringan mempengaruhi perbungaan $(\mathrm{P}<0.001)$. Pada tanaman kontrol, rata-rata jumlah bunga membentuk polong adalah 3.01 (0.41), kekeringan pada fase inisiasi bunga $2.00(0.51)$, kekeringan pada fase berbunga $2.20(0.25)$ dan kekeringan pada fase pembentukan polong adalah 2.00 (0.40). Jadi, semua perlakuan deraan kekeringan menyebabkan jumlah bunga membentuk polong menurun (Gambar 2a). Deraan kekeringan juga mempengaruhi produksi polong $(\mathrm{P}<0.001)$. Pada tanaman kontrol, rata-rata jumlah polong yang dihasilkan adalah 8.00 (1.24), kekeringan pada fase inisiasi bunga 4.40 (1.51), kekeringan pada fase berbunga $3.80(0.95)$ dan kekeringan pada fase pembentukan polong adalah 5.20 (1.11). Jadi, semua perlakuan deraan kekeringan menyebabkan hasil polong menurun (Gambar $2 b)$.

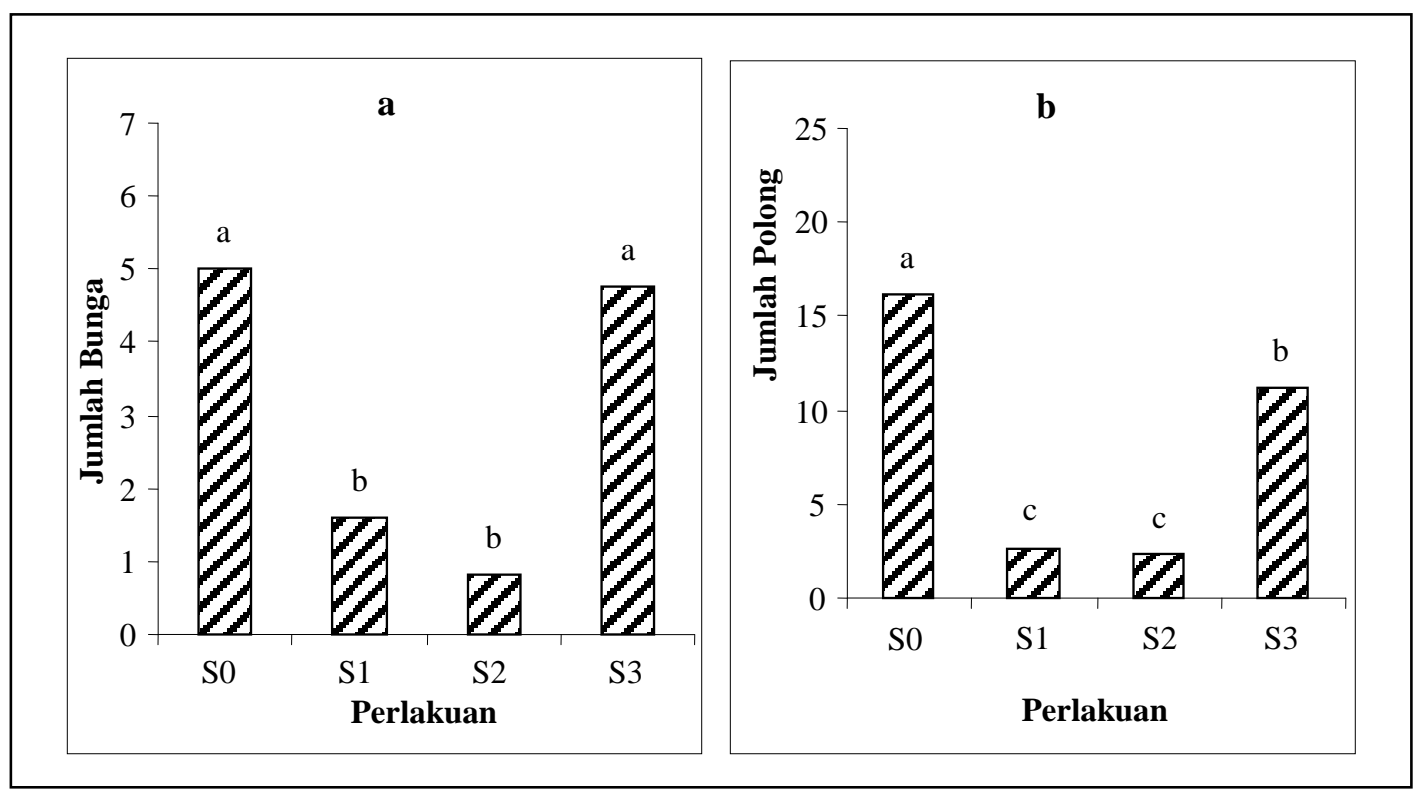

Gambar 1. Jumlah bunga membentuk polong (a) dan jumlah polong (b) pada varietas Belu. Tidak ada perlakuan deraan kekeringan (kontrol,S0), deraan kekeringan pada fase inisiasi bunga (S1), fase berbunga (S2) dan fase pembentukan polong (S3). Nilai diikuti oleh huruf yang sama tidak berbeda nyata antar rata-rata menurut uji Tukey. 


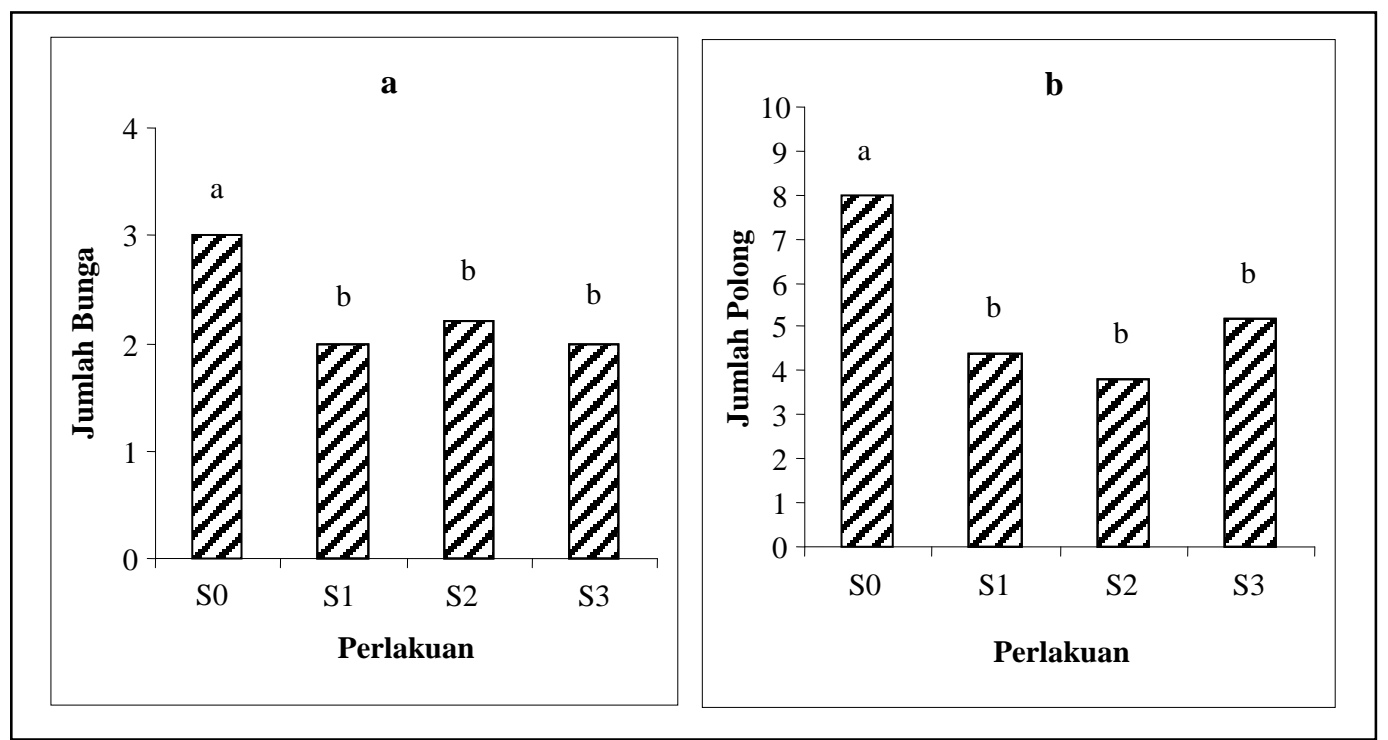

Gambar 2. Jumlah bunga membentuk polong (a) dan jumlah polong (b) pada varietas Perkutut. Tidak ada perlakuan deraan kekeringan (kontrol, S0), deraan kekeringan pada fase inisiasi bunga (S1), fase berbunga (S2) dan fase pembentukan polong (S3). Nilai diikuti oleh huruf yang sama tidak berbeda nyata antar rata-rata menurut uji Tukey.

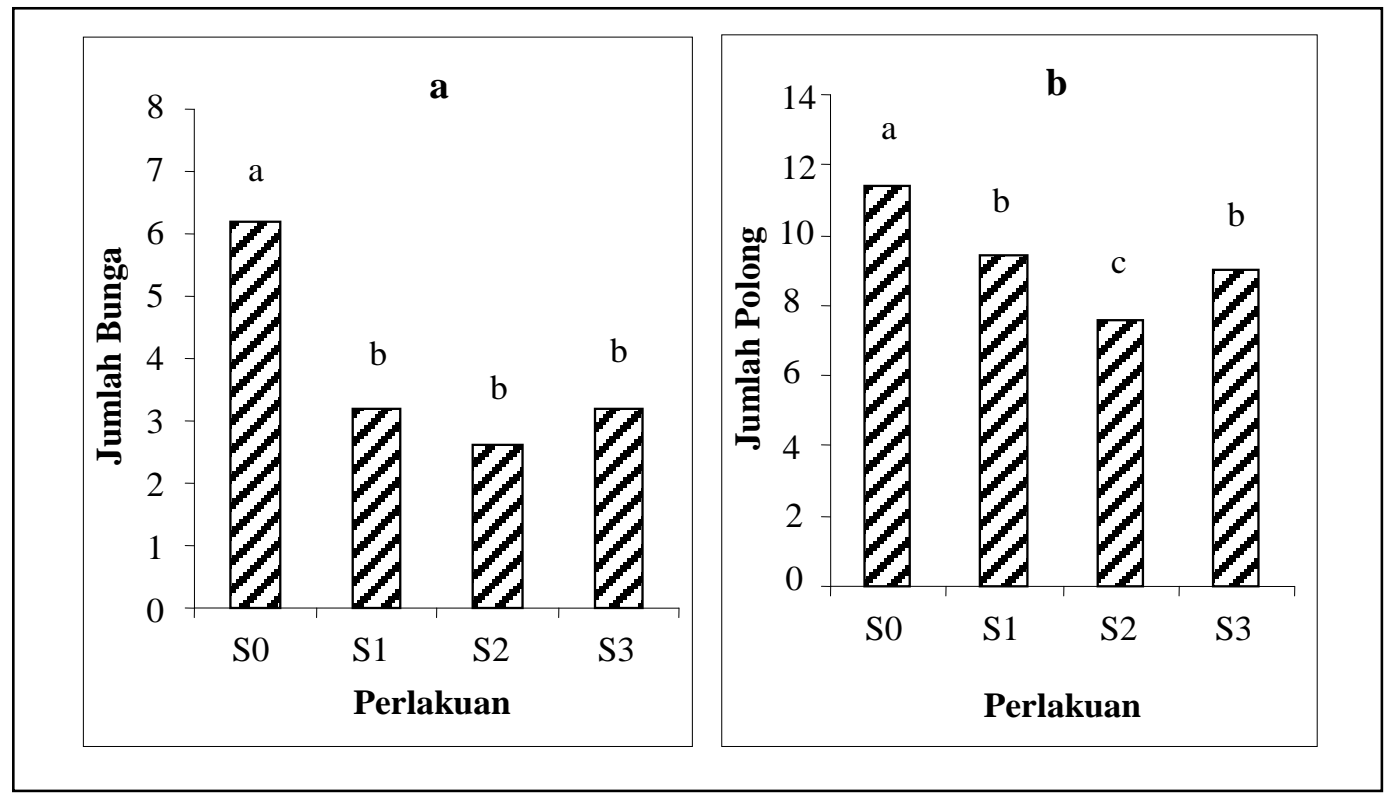

Gambar 3. Jumlah bunga membentuk polong (a) dan jumlah polong (b) pada varietas Kenari. Tidak ada perlakuan deraan kekeringan (kontrol,S0), deraan kekeringan pada fase inisiasi bunga (S1), fase berbunga (S2) dan fase pembentukan polong (S3). Nilai diikuti oleh huruf yang sama tidak berbeda nyata antar rata-rata menurut uji Tukey. 


\section{Varietas Kenari}

Deraan kekeringan pada varietas Kenari mempengaruhi jumlah bunga membentuk polong $(\mathrm{P}<0.001)$. Pada tanaman kontrol, ratarata jumlah bunga membentuk polong adalah 6.20 (1.10), kekeringan pada fase inisiasi bunga 3.20 (0.95), kekeringan pada fase berbunga 2.60 (0.44) dan kekeringan pada fase pembentukan polong adalah 3.20 (0.34). Jadi, semua perlakuan deraan kekeringan menyebabkan jumlah bunga membentuk polong menurun (Gambar 3a). Deraan kekeringan juga mempengaruhi $(\mathrm{P}<0.001)$ polong yang dihasilkan (Gambar 3b). Pada tanaman kontrol, rata-rata jumlah polong per tanaman adalah 11.40 (1.20), kekeringan pada fase inisiasi bunga 9.40 (1.24), kekeringan pada fase berbunga 7.60 (1.41) dan kekeringan pada fase pembentukan polong adalah $9.00(0.42)$. Deraan kekeringan pada fase berbunga tampaknya lebih berdampak negatif terhadap pembentukan polong dibanding dengan deraan kekeringan pada fase lainnya. Oleh sebab itu, fase reproduksi varietas Kenari yang paling rentan terhadap deraan kekeringan adalah fase berbunga.

\section{Varietas Murai}

Pada varietas Murai, deraan kekeringan juga mempengaruhi jumlah bunga membentuk polong $(\mathrm{P}<0.001)$. Pada tanaman kontrol, ratarata jumlah bunga membentuk polong adalah 5.80 (1.02), kekeringan pada fase inisiasi bunga 3.40 (1.19), kekeringan pada fase berbunga 2.80 (0.83) dan kekeringan pada fase pembentukan polong adalah 3.20 (0.91). Semua perlakuan deraan kekeringan menyebabkan jumlah bunga membentuk polong menurun (Gambar 4a). Deraan kekeringan juga mempengaruhi $\quad(\mathrm{P}<0.001)$ jumlah polong (Gambar 4b). Pada tanaman kontrol, rata-rata jumlah polong adalah 14.00 (1.64), kekeringan pada fase inisiasi bunga 8.40 (2.11), kekeringan pada fase berbunga 6.20 (1.03) dan deraan kekeringan pada fase pembentukan polong adalah 6.60 (1.79). Tampaknya, deraan kekeringan pada fase berbunga dan pembentukan polong lebih berdampak negatif terhadap pembentukan polong dibanding dengan perlakuan lainnya.

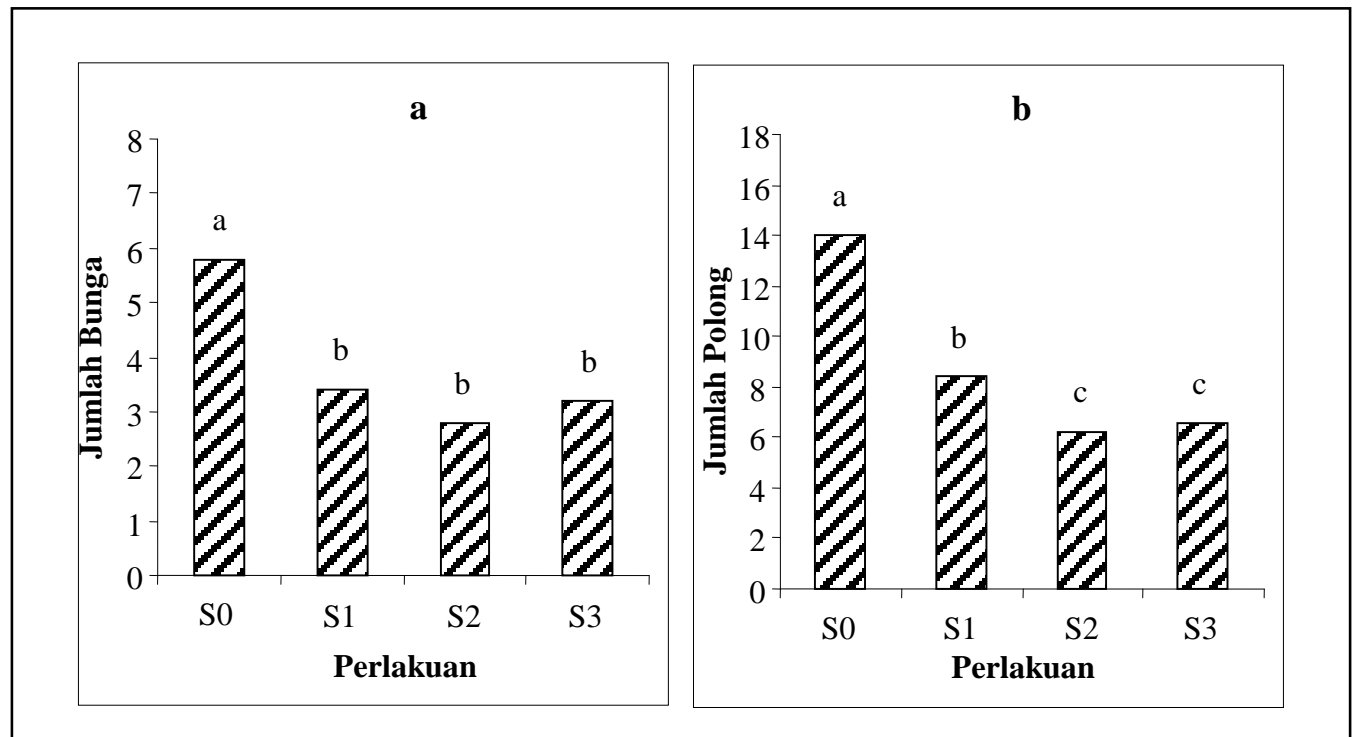

Gambar 4. Jumlah bunga membentuk polong (a) dan jumlah polong (b) pada varietas Murai. Tidak ada perlakuan deraan kekeringan (kontrol,S0), deraan kekeringan pada fase inisiasi bunga (S1), fase berbunga (S2) dan fase pembentukan polong (S3). Nilai diikuti oleh huruf yang sama tidak berbeda nyata antar rata-rata menurut uji Tukey. 


\section{Perbedaan antar perlakuan varietas dan kekeringan}

Jumlah bunga membentuk polong $(\mathrm{P}=0.022)$ dan produksi polong $(\mathrm{P}<0.001)$ berbeda antar varietas yaitu lebih rendah pada varietas Perkutut dibanding dengan varietas lainnya (Tabel 1). Deraan kekeringan juga mempengaruhi jumlah bunga membentuk polong $(\mathrm{P}<0.001)$ dan produksi polong $(\mathrm{P}<0.001)$. Deraan kekeringan pada fase reproduksi, baik pada fase inisiasi bunga, fase berbunga dan fase pembentukan polong menyebabkan jumlah bunga membentuk polong dan produksi polong menurun.

Berdasarkan parameter jumlah bunga membentuk polong dan produksi polong, secara umum deraan kekeringan pada fase inisiasi bunga dan berbunga lebih berdampak negatif pada varietas Belu dibanding dengan varietas lainnya dimana jumlah bunga membentuk polong dan produksi polong lebih rendah (Tabel 2). Namun demikian, varietas Belu relatif lebih toleran terhadap deraan kekeringan pada fase pembentukan polong dibanding dengan varietas lainnya. Berdasarkan produksi dan toleransinya terhadap deraan kekeringan, varietas Kenari dan Murai lebih baik dibudidayakan dibanding dengan varietas Belu dan Perkutut karena produksinya relatif lebih tinggi dan lebih toleran terhadap deraan kekeringan baik pada fase inisiasi bunga, fase berbunga dan fase pembentukan polong.

Tabel 1. Rata-rata jumlah bunga membentuk polong dan produksi polong.

\begin{tabular}{llrr}
\hline \multicolumn{2}{c}{ Perlakuan } & Jumlah Bunga & \multicolumn{1}{c}{ Jumlah Polong } \\
\hline \hline Varietas & Belu & $2.95(2.27) \mathrm{ab}$ & $7.95(7.59) \mathrm{a}$ \\
& Kenari & $3.80(1.67) \mathrm{a}$ & $9.35(2.77) \mathrm{a}$ \\
& Murai & $3.80(1.98) \mathrm{a}$ & $8.80(4.80) \mathrm{a}$ \\
& Perkutut & $2.30(0.80) \mathrm{b}$ & $5.35(2.94) \mathrm{b}$ \\
\hline Deraan & S0 & $5.00(1.80) \mathrm{a}$ & $12.40(4.33) \mathrm{a}$ \\
Kekeringan & S1 & $2.55(1.54) \mathrm{b}$ & $6.20(4.72) \mathrm{b}$ \\
& S2 & $2.10(1.21) \mathrm{b}$ & $5.00(3.55) \mathrm{b}$ \\
& S3 & $3.21(1.36) \mathrm{b}$ & $7.84(4.26) \mathrm{b}$ \\
\hline \hline
\end{tabular}

Keterangan: Tidak ada perlakuan deraan kekeringan sebagai kontrol (S0), deraan kekeringan pada fase inisiasi bunga (S1), fase berbunga (S2) dan fase pembentukan polong (S3). Nilai rata-rata pada kolom yang sama diikuti oleh huruf yang sama tidak berbeda nyata antar rata-rata menurut uji Tukey. Tidak ada huruf = analisis tidak berbeda nyata.

Tabel 2. Rata-rata jumlah bunga membentuk polong dan produksi polong menurut kombinasi perlakuan varietas dan deraan kekeringan.

\begin{tabular}{llrrrr}
\hline \hline & Deraan Kekeringan & \multicolumn{1}{c}{ Belu } & \multicolumn{1}{l}{ Kenari } & \multicolumn{1}{l}{ Murai } & \multicolumn{1}{c}{ Perkutut } \\
\hline \hline Jumlah Bunga & S0 & $5.00(1.21) \mathrm{a}$ & $6.20(1.10) \mathrm{a}$ & $5.80(1.02) \mathrm{a}$ & $3.01(0.41) \mathrm{b}$ \\
& S1 & $1.60(0.84) \mathrm{b}$ & $3.20(0.95) \mathrm{a}$ & $3.40(1.19) \mathrm{a}$ & $2.00(0.51) \mathrm{b}$ \\
& S2 & $0.80(0.30) \mathrm{c}$ & $2.60(0.44) \mathrm{a}$ & $2.80(0.83) \mathrm{a}$ & $2.20(0.25) \mathrm{b}$ \\
& S3 & $4.75(1.05)$ & $3.20(0.34)$ & $3.20(0.91)$ & $2.00(0.40)$ \\
\hline Jumlah Buah & S0 & $16.20(2.86) \mathrm{a}$ & $11.40(1.20) \mathrm{b}$ & $14.00(1.64) \mathrm{a}$ & $8.00(1.24) \mathrm{bc}$ \\
& S1 & $2.60(0.94) \mathrm{b}$ & $9.40(1.24) \mathrm{a}$ & $8.40(2.11) \mathrm{a}$ & $4.40(1.51) \mathrm{b}$ \\
& S2 & $2.40(0.82) \mathrm{b}$ & $7.60(1.41) \mathrm{a}$ & $6.20(1.03) \mathrm{a}$ & $3.80(0.95) \mathrm{b}$ \\
& S3 & $11.25(2.18) \mathrm{a}$ & $9.00(0.42) \mathrm{b}$ & $6.60(1.79) \mathrm{bc}$ & $5.20(1.11) \mathrm{c}$ \\
\hline \hline
\end{tabular}

Keterangan: Tidak ada perlakuan deraan kekeringan sebagai kontrol (S0), deraan kekeringan pada fase inisiasi bunga (S1), fase berbunga (S2) dan fase pembentukan polong (S3). Nilai rata-rata pada baris yang sama diikuti oleh huruf yang sama tidak berbeda nyata antar rata-rata menurut uji Tukey. 
Deraan kekeringan dapat menyebabkan pengaruh besar pada pertumbuhan dan perkembangan tumbuhan. Gejala paling umum dari deraan kekeringan adalah layunya daun akibat tekanan air dalam daun menurun. Jika tumbuhan mengalami deraan kekeringan, akan lebih banyak energi digunakan untuk mengambil air sehingga tumbuhan akan mengalami stres. Konsekuensi utama dari deraan kekeringan adalah menurun fotosintesis. Stomata merupakan sel tumbuhan yang mengontrol keluar masuknya air, $\mathrm{CO}_{2}$ dan $\mathrm{O}_{2}$ dalam daun. Jika deraan kekeringan terjadi, stomata akan menutup untuk memelihara kandungan air namun menutupnya stomata akan menghambat pertukaran air, $\mathrm{CO}_{2}$ dan $\mathrm{O}_{2}$ sehingga fotosintesis menurun (Pearson, 2008). Selain mempengaruhi laju fotosintesis, deraan kekeringan juga dapat menyebabkan perubahan fisiologi lainnya seperti laju respirasi dan kandungan osmoregulator sebagai adaptasi tumbuhan terhadap kondisi lingkungan (Levitt 1980).

Siddique et al., (2000) menyatakan, deraan kekeringan pada Triticum aestivum mengurangi potensial air daun dan kandungan air daun. Semakin tinggi potensial air daun dan kandungan air daun semakin tinggi laju fotosintesisnya. Temperatur daun tanaman yang mengalami deraan kekeringan lebih tinggi dibanding tanaman yang mendapat cukup air dan lebih tinggi temperatur daun lebih rendah laju fotosintesisnya. Lebih rendahnya laju fotosintesis daun yang temperaturnya tinggi disebabkan lebih tingginya respirasi pada daun tersebut. Deraan kekeringan juga menyebabkan temperatur penutupan (canopy) meningkat. Meningkatnya temperatur daun dan penutupan tanaman yang mengalami deraan kekeringan disebabkan meningkatnya respirasi dan menurunnya tansfirasi daun tersebut akibat penutupan stomata.

Siddique et al., (2000) juga menyatakan bahwa pada fase pertumbuhan vegetatif, pemberian air setelah tanaman mengalami deraan kekeringan kemungkinannya tumbuh kembali lebih besar. Namun, jika deraan kekeringan terjadi pada fase reproduksi, pertumbuhan berikutnya akan terhambat. Fischer dan Sanchez (1979) mengemukakan, jika deraan kekeringan terjadi pada bagian akhir siklus hidup tanaman pangan annual sedikit kemungkinannya tumbuh kembali. Semakin dekat tanaman ke masa matang semakin kurang fleksibel tanaman tersebut tumbuh kembali setelah mengalami deraan kekeringan dan semakin awal deraan kekeringan terjadi semakin kecil efeknya pada hasil akhir. Pearson (2008) mengemukakan, tanaman pangan legum seperti kacangkacangan umumnya resisten terhadap deraan kekeringan pada fase vegetatif namun tidak resisten pada fase reproduksi. Tumbuhan tersebut membutuhkan jumlah tertentu air untuk dapat bereproduksi dengan baik dan proses reproduksi dapat terganggu akibat deraan kekeringan dan umumnya tidak dapat tumbuh kembali setelah deraan kekeringan berahir.

Data fisiologi lainnya mengenai respon tumbuhan terhadap deraan kekeringan telah banyak tersedia (Kuppers et al., 1988; Cruz de Carvalho et al., 1998; Collino et al., 2001). Perbedaan pada parameter integritas membran dan kandungan protein akibat deraan kekeringan sudah diteliti pada sejumlah kacang-kacangan. Cruz de Carvalho et al., (1998), membandingkan respon Phaseolus vulgaris dan Vigna unguiculata terhadap deraan kekeringan. $P$. vulgaris lebih sensitif terhadap deran kekeringan dibanding $V$. unguiculata. Pada kondisi kekeringan, $P$. vulgaris menutup stomata lebih cepat sehingga laju assimilasinya menurun lebih banyak sedangkan $V$. unguiculata dapat menyesuaikan stomata sehingga dapat mempertahankan fotosintesis lebih lama. $V$. unguiculata mempunyai kapasitas lebih baik menyesuaikan stomata dan memelihara stomata sebagian terbuka jika mengalami deraan kekeringan. Juga ditemukan, penutupan stomata $P$. vulgaris terjadi pada kandungan air substrat dan potensial air daun yang lebih tinggi dibanding dengan $V$. unguiculata. Jika terjadi deraan kekeringan, tumbuhan yang rentan terhadap deraan kekeringan stomatanya cepat menutup sehingga menurun laju fotosintesisnya sedangkan tumbuhan yang resisten memelihara konduktanse stomatanya walau kandungan air substrat rendah dan mempertahankan fotosintesisnya sehingga hasilnya lebih tinggi. 
Produksi atau hasil panen yang di peroleh dari budidaya tanaman pertanian umumnya diperoleh dari hasil perkembangan organ-organ reproduksi tanaman tersebut. Sebab sebagian besar tanaman pada tahap tertentu dalam siklus hidupnya mengalami deraan kekeringan, pengaruh dari deraan kekeringan tersebut terhadap perkembangan organ-organ reproduksi penting diketahui. Hasil penelitian menunjukkan, bahwa deraan kekeringan pada fase reproduksi baik pada fase inisiasi bunga, fase berbunga dan fase pembentukan polong semuanya mempengaruhi produksi tanaman kacang hijau yaitu jumlah bunga dan polong yang dihasilkan menurun. Deraan kekeringan pada fase reproduksi menyebabkan bunga dan polong terutama berukuran kecil gugur.

Hasil penelitian Husain et al., (1990) dan Xia (1994) pada $V$. faba menunjukkan bahwa deraan kekeringan menyebabkan menurunnya perpanjangan tajuk dan perkembangan daun, area daun lebih kecil, daun gugur dan produksi berat kering tajuk menurun. Selain itu, laju fotosintesis, ukuran stomata dan hasil biji juga menurun. Pada gandum, deraan kekeringan pada saat antesis mengurangi jumlah biji per bunga sedang jumlah bunga atau ukuran biji tidak berpengaruh (Saini dan Aspinal, 1981). Hal ini menunjukkan bahwa deraan kekeringan mempengaruhi fertilisasi.

Sensifitas kacang hijau terhadap deraan kekeringan berbeda antar varietas dan pada tiap fase fenologi reproduksi tanaman. Pada varietas Belu, deraan kekeringan pada fase inisiasi bunga dan fase berbunga lebih berdampak negatif terhadap produksi polong dibanding dengan deraan kekeringan pada fase pembentukan polong. Pada varietas Kenari, deraan kekeringan pada fase berbunga lebih berdampak negatif terhadap pembentukan bunga dan polong dibanding dengan deraan kekeringan pada fase lainnya. Pada varietas Murai, deraan kekeringan pada fase berbunga dan pembentukan polong lebih berdampak negatif terhadap produksi polong dibanding dengan deraan kekeringan pada fase inisiasi bunga.

Xia (1994), menemukan bahwa sensifitas $V$. faba terhadap deraan kekeringan berbeda pada tiap fase fenologi perkembangan tanaman.
Tanaman yang mengalami deraan kekeringan pada fase inisiasi bunga, biji yang dihasilkan tidak terpengaruh sedang tanaman yang mengalami deraan kekeringan dari awal sampai akhir pembentukan polong bijinya berkurang sampai $45 \%$. Deraan kekeringan setelah berbunga akan mengurangi jumlah polong dan biji pertanaman sampai 38\% sedang jika deraan kekeringan terjadi selama fase pengisian polong berat bijinya lebih rendah dari pada tanaman yang cukup air. El Nadi (1969) menemukan pada $V$. faba, bahwa fase berbunga lebih sensitif terhadap deraan kekeringan dari pada fase vegetatif.

Secara umum, pada tanaman kacang hijau, deraan kekeringan pada fase reproduksi menyebabkan pembentukan bunga dan buah menurun. Oleh sebab itu, dalam budidaya, ketersediaan air (irigasi) dan kesesuaian musim tanam dengan curah hujan dan fase reproduksi tanaman perlu mendapat perhatian untuk memperoleh hasil yang optimal. Pada banyak spesies, curah hujan merupakan prasyarat penting untuk berbunga dan sangat penting pada pembentukan buah. Diduga curah hujan diperlukan untuk menginduksi bunga dan hujan lebih lanjut diperlukan sesudah berbunga untuk mempromosi pembentukan polong dan biji. Ketidak hadiran hujan pada tahap terahir dapat menyebabkan sebagian polong gugur dan tidak membentuk biji dengan baik. Pada tanaman Acacia, irigasi menstimulasi perbungaan dan pembentukan buah (Preece, 1971). Davies (1968) melaporkan bahwa pada spesies di daerah beriklim kering, curah hujan diperlukan untuk menstimulasi perbungaan dan hujan yang lebih banyak diperlukan utuk dapat membentuk biji dengan baik. Porter (1978) juga melaporkan bahwa hujan menstimulasi perbungaan dan formasi pucuk dan pucuk bunga dan buah akan rusak jika terjadi deraan kekeringan.

\section{Kesimpulan dan Saran}

\section{Kesimpulan}

Pada keempat varietas kacang hijau, deraan kekeringan pada fase reproduksi menyebabkan jumlah bunga dan polong menurun. Berdasarkan parameter pembentukan 
bunga dan buah, fase reproduksi yang paling rentan terhadap deraan kekeringan pada varetas Belu adalah fase inisiasi bunga dan berbunga; pada varietas Kenari fase berbunga; pada varietas Murai fase berbunga dan pembentukan polong sedang pada varietas Perkutut semua fase reproduksi kerentanannya terhadap deraan kekeringan relatif sama. Jumlah bunga membentuk polong dan produksi polong lebih tinggi pada varietas Kenari dan Murai dibanding dengan varietas Perkutut dan Belu. Berdasarkan parameter jumlah bunga membentuk polong dan produksi polong, deraan kekeringan pada fase inisiasi bunga dan berbunga lebih berdampak negatif pada varietas Belu dan Perkutut dibanding dengan varietas Perkutut dan Murai. Deraan kekeringan pada fase pembentukan polong juga lebih berdampak negatif terhadap varietas Perkutut dibanding varietas lainnya.

\section{Saran}

Pada pertanaman kacang hijau, deraan kekeringan selama fase reproduksi perlu dihindari dan fase reproduksi yang sensitif terhadap deraan kekeringan perlu mendapat perhatian untuk memperoleh hasil yang optimal. Berdasarkan produksi tanaman dan toleransinya terhadap deraan kekeringan, varitas Kenari dan Murai lebih baik dibudidayakan dibanding dengan varietas Belu dan Perkutut.

\section{Ucapan Terima Kasih}

Penelitian ini merupakan bagian dari penelitian "Dampak Deraan Kekeringan Terhadap Reproduksi Empat Varietas Vigna radiata L" yang dibiayai Program Insentif Riset Dasar Kementerian Riset dan Teknologi Tahun Anggaran 2008.

\section{Daftar Pustaka}

Collino, D.J., Dardanelli, J.L., Sereno, R. and Racca, R.W. 2001. Physiological Responses of Argentine Peanut Varieties to Water Stress. Lihgt Interception, Radiation use Efficiency and Partitioning of Assimilates. Field Crops Research 70: 177-184.
Cruz de Carvalho, M.H., Laffray, D. and Louquet, P. 1998. Comparison of The Physiological Responses of Phaseolus vulgaris and Vigna unguiculata Cultivars When Submitted to Drought Conditions. Environmental and Experimental Botany 40: 197-207.

Davies, S.J.J.F. 1968. Aspects of a Study of Emus in Semi-arid Western Australia. Proceeding Ecological Society of Australia 3: 160-166.

El Nadi, A.H. 1969. Water Relations of Beans I. Effect of Water Stress on Growth and Flowering. Expl. Agric 5: 195- 207.

Fischer, R.A. and Sanchez, M. 1979. Drought Resistance in Spring Wheat Cultivars. II. Effects on Plant Water Relations. Aust. J. Agric. Res. 30: 801814.

Hakim, L. 2008. Konservasi dan Pemanfaatan Sumber Daya Genetik Kacang Hijau. J. Litbang Pertanian 27 (1): 16-23.

Husain, M.M., Reid, J.B., Othman, H. and Gallagher, J.N. 1990. Growth and Water Use of Faba Beans (Vicia faba) in a Sub-humid Climate. I. Root and Shoot Adaptation to Drought Stress. Field Crops Research 23: 1-17.

Kuppers, B.I.L., Kuppers, M. and Schulze, E.D. 1988. Soil Drying and Its Effect on Leaf Conductance and $\mathrm{CO}_{2}$ Assimilation of Vigna unguiculata (L.). Walp. I The Response to Climate Factors and to The Rate of Soil Drying in Young Plants. Oecologia 75: 99104.

Levitt, J. 1980. Respond of Plant to Environmental Stress. Academic Press, New York.

Moenandir, J., Sarjono, S. dan Budiwati, H. 1990. Periode Kritis Tanaman Kacang Hijau (Vigna radiata L) Varietas Wallet Karena Adanya Persaingan dengan Gulma dan Jenis Pengolahan Tanah. Pros. I Konferensi X Himpunan Ilmu Gulma Indonesia. Malang.

Mwanamwenge, J., Loss, S.P., Siddique, K.H.M. and Cocks, P.S. 1999. Effect of Water Stress During Floral Initiation, Flowering and Podding on The Growth and Yield of Faba Bean (Vicia faba L.). European J. of Agronomy 11: 1-11.

Pearson, K. 2008. How and When does Water Stress Impact Plant Growth and Development. Montana State University. Bozeman.

Porter, J.W. 1978. Relationship Between Flowering and Honey Production of Red Ironbark, Eucalyptus sideroxylon (A. Cunn.) Benth. and Climate in The Bendigo District of Victoria. Australian J. of Agricultural Research 29: 815-829. 
Preece, P.B. 1971. Contributions to The Biology of Mulga. I. Flowering. Australian J. of Botany 19: 21-38.

Rukmana. 1997. Kacang Hijau, Budidaya dan Pengolahan Pasca Panen. Kanisius. Yogyakarta.

Saini, H.S. and Aspinal, D. 1981. Effect of Water Deficit on Sporogenesis in Wheat (Triticum aestivum L.). Annal of Botany 48: 623-633.

Sathyamoorthi, K., Amanullah, M.M., Somasundaram, E., Pazhanivelan, S. and Vaiyapuri, K. 2008. Root Growth and Yield of Greengram (Vigna radiata (L.) Wilczek) as Influenced by Increased Plant Density and Nutrient Management. J. of Appl. Sciences Research 4 (7): 917-924.

Siddique, M.R.B., Hamid, A. and Islam, M.S. 2000. Drought Stress Effects on Water Relations of Wheat. Bot. Bull. Acad. Sin 41:35-39.
Sumarno, Pasaribu, D. dan Hartono. 1993. Teknologi Peningkatan Produksi Kacang-kacangan dan Perbaikan Giji Masyarakat. Pros. Simposium Penelitian Tanaman Pangan II. Jakarta/Bogor. Hal: 267-285.

Xia, M.Z. 1994. Effect of Soil Drought during the Generative Development Phase of Faba Bean (Vicia faba) on Photosynthetic Character and Biomass Production. J. of Agricultural Science 122: 67-72.

Xia, M.Z. 1997. Effect of Soil Drought during The Generative Development Phase on Seed Yield and Nutrient Uptake of Faba Bean (Vicia faba). Australian J. of Agricultural Research 48: 447-451. 